\title{
Ozone induces BEL7402 cell apoptosis by increasing reactive oxygen species production and activating JNK
}

\author{
Shuiying Tang ${ }^{1}$, Bihong $\mathrm{Xu}^{2}$, Jincheng $\mathrm{Li}^{1}$, Meifeng Zhong ${ }^{3}$, Ziyang Hong ${ }^{3}$, Wei Zhao ${ }^{1}$, Tao Zeng ${ }^{3}$, \\ Xiaofeng $\mathrm{He}^{1}$ \\ ${ }^{1}$ Division of Vascular and Interventional Radiology, Department of General Surgery, Nanfang Hospital, Southern Medical University, Guangzhou, \\ China; ${ }^{2}$ Interventional Radiology and Pathology, Nanfang Hospital, Department of Pathology, Southern Medical University, Guangzhou, China; \\ ${ }^{3}$ Laboratory Medicine Center, Nanfang Hospital, Southern Medical University, Guangzhou, China \\ Contributions: (I) Conception and design: S Tang; (II) Administrative support: X He, T Zeng; (III) Provision of study materials or patients: J Li, M \\ Zhong, Z Hong; (IV) Collection and assembly of data: B Xu; (V) Data analysis and interpretation: W Zhao; (VI) Manuscript writing: All authors; (VII) \\ Final approval of manuscript: All authors. \\ Correspondence to: Xiaofeng He. Division of Vascular and Interventional Radiology, Department of General Surgery, Nanfang Hospital, Southern \\ Medical University, 1838 Guangzhou Avenue North, Guangzhou 510515, China. Email: ozonetherapy@126.com.
}

\begin{abstract}
Background: Oxidative stress is an important factor in the modulation of both tumorigenesis and anticancer responses. Ozone $\left(\mathrm{O}_{3}\right)$ is a strong oxidant that causes redox reactions and exerts anticancer effects in various types of cancer cells. However, the pathways involved in $\mathrm{O}_{3}$-induced cell death are not well understood.

Methods: In vitro human hepatocellular carcinoma (HCC) BEL7402 cells were treated with various $\mathrm{O}_{3}$ concentrations to evaluate $\mathrm{O}_{3}$ cytotoxicity by Cell Counting Kit-8 (CCK-8) assay and flow cytometry. The regulatory mechanisms were analyzed by western blot analysis. In vivo, an HCC model was established to evaluate the inhibition of $\mathrm{HCC}$ with $\mathrm{O}_{3}$ treatment.

Results: In vitro cells treated with $\mathrm{O}_{3}$ exhibited a round and small morphology with nuclear shrinkage and fragmentation. The CCK-8 assay confirmed the potent cytotoxic activity of $\mathrm{O}_{3}$ against BEL7402 cells $\left(\mathrm{IC}_{50}\right.$ value of $5 \mu \mathrm{g} / \mathrm{mL}$ ). Acridine orange/ethidium bromide (AO/EB) staining revealed apoptosis of BEL7402 cells after $\mathrm{O}_{3}$ treatment. Flow cytometry analysis showed that $\mathrm{S}$ phase cell cycle arrest and apoptosis increased with $\mathrm{O}_{3}$ exposure. In addition, $\mathrm{O} 3$ exposure reduced the mitochondrial membrane potential $(\Delta \Psi \mathrm{m})$ and induced reactive oxygen species (ROS) accumulation. Western blot analysis showed that $\mathrm{O}_{3}$ exposure reduced B-cell lymphoma 2 (BCL-2) expression and increased cleaved poly ADP-ribose polymerase (PARP), cytochrome C (Cyt-C), caspase-3, caspase-9, and p-JNK expression. In vivo, treatment with intratumor injection $\mathrm{O}_{3}(20 \mu \mathrm{g} / \mathrm{mL})$ inhibited HCC growth.

Conclusions: Overall, our findings showed that $\mathrm{O}_{3}$ induces BEL7402 cell apoptosis via the intrinsic mitochondria-dependent pathway. Therefore, $\mathrm{O}_{3}$ has therapeutic potential for HCC.
\end{abstract}

Keywords: Ozone $\left(\mathrm{O}_{3}\right)$; hepatocellular carcinoma (HCC); apoptosis; reactive oxygen species (ROS)

Submitted Jun 04, 2021. Accepted for publication Jul 14, 2021.

doi: $10.21037 / \mathrm{atm}-21-3233$

View this article at: https://dx.doi.org/10.21037/atm-21-3233

\section{Introduction}

Primary liver cancer is the sixth most common cancer and the second leading cause of cancer-related death in the world. The most prevalent pathological type of liver cancer is hepatocellular carcinoma (HCC), which accounts for more than $85 \%$ of all cases. It is one of the most prevalent and high-grade malignant tumors of the digestive tract (1). The overall prognosis of HCC is poor, with a 5 -year overall survival (OS) of $24-41 \%$ (2). Surgery is the first method of treatment for HCC. The 5 -year survival rate after surgical 
resection is $20-40 \%$. If the tumor is $<5 \mathrm{~cm}$, the 5 -year survival rate may reach $60 \%$. As most patients are diagnosed with advanced stage HCC due to insidious chronic liver disease, surgery is only suitable for $9-27 \%$ of HCC patients. The 5-year survival rate and survival benefit of local ablation and transarterial chemoembolization are $50-70 \%$ and $>6$ months, respectively. However, this treatment is limited to HCC patients with single or multinodular tumors and good liver function $(3,4)$. Sorafenib, a multi-tyrosine kinase inhibitor (MTKI), was the only clinical first-line medication approved for advanced liver cancer for more than a decade until lenvatinib, another MTKI, was approved. However, MTKIs only prolong survival for $\sim 3$ months $(5,6)$. Although hepatectomy and liver transplantation partially improve the survival rate of HCC, the result of necessary longterm adjuvant chemotherapy is limited due to the different tolerances of patients to side effects $(7,8)$. Thus, a new and more widely applicable treatment strategy for liver cancer is urgently needed.

Ozone $\left(\mathrm{O}_{3}\right)$ therapy is an efficacious adjuvant treatment for different diseases, such as mucositis, psoriasis, acute pain, neurovascular disease, and cancer $(9,10)$. Previous studies have proposed the ability of $\mathrm{O}_{3}$ to cause direct injury to tumor cells. In 1980, Science published an article about the selective inhibition of tumor cell growth by $\mathrm{O}_{3}$ in different human tumor cells in vitro, including lung, breast, and uterine tumor cells, without affecting the growth of nontumor cell lines (11). A 1987 study showed the cytotoxic effects of medical $\mathrm{O}_{3}$ on ovarian cancer cells, but not on endometrial cancer cells (12). In 2007, Cannizzaro showed that $\mathrm{O}_{3}$ enhanced the effects of cisplatin and etoposide on cultured neuroblastoma cells (13). Kuroda et al. studied the effects of $\mathrm{O}_{3}$ water on rectal cancer and concluded that topical application of $\mathrm{O}_{3}$ water did not harm normal tissues; however, direct topical application of $\mathrm{O}_{3}$ water to tumor tissues induced necrosis and inhibited tumor cell proliferation (14). Thus, $\mathrm{O}_{3}$ has shown variable effects on different tumors in cell culture. It remains to be determined whether $\mathrm{O}_{3}$ can inhibit the growth of HCC cells.

In this study, we applied $\mathrm{O}_{3}$ to human HCC BEL7402 cells in vitro and observed the cellular effects by morphological observation, acridine orange/ethidium bromide (AO/EB) staining, and flow cytometry analysis. Expression of apoptosis proteins upon $\mathrm{O}_{3}$ treatment was detected by western blot. We found that $\mathrm{O}_{3}$ promotes reactive oxygen species (ROS)-mediated cell death in HCC cells, In vivo, treatment of intratumor injection $\mathrm{O}_{3}$
$(20 \mu \mathrm{g} / \mathrm{mL})$ inhibited HCC growth. We demonstrate for the first time that $\mathrm{O}_{3}$ can cause HCC cell death through an endogenous apoptotic pathway, which is associated with oxidative stress. This is a new therapeutic strategy.

We present the following article in accordance with the ARRIVE reporting checklist (available at https://dx.doi. org/10.21037/atm-21-3233).

\section{Methods}

\section{Cell culture and treatment}

Human HCC cell line BEL7402 was purchased from Scientific Laboratories of Southern Medical University (Guangzhou, Guangdong, China). BEL7402 cells were cultured in Roswell Park Memorial Institute (RPMI)-1640 medium (Gibco, Waltham, MA, USA) supplemented with $10 \%$ fetal bovine serum (FBS; Kang Yuan Biology, Tianjin, China), $100 \mathrm{~g} / \mathrm{mL}$ streptomycin, and $100 \mu \mathrm{g} / \mathrm{mL}$ penicillin (Gibco, USA) at $37{ }^{\circ} \mathrm{C}$ in an incubator with $95 \%$ air and $5 \% \mathrm{CO}_{2}$. When the cells reached $\sim 80 \%$ confluence, they were divided into a control group and experimental groups, and the experimental groups were treated with different concentrations of $\mathrm{O}_{3}$. Cultures were injected with $10 \mathrm{~mL}$ of $\mathrm{O}_{3}$ and the dishes were sealed and incubated for $15 \mathrm{~min}$ in the dark. Then, the $\mathrm{O}_{3}$ was released, fresh medium was added, and cells were incubated for $24 \mathrm{~h}$ for follow-up experiments.

\section{Inverted microscope analysis}

A Leica XSP-8CA microscope (Leica, Wetzlar, Germany) was used to observe the morphology of apoptotic cells. After $\mathrm{O}_{3}$ treatment, cells were washed with phosphatebuffered saline (PBS) and placed under the microscope for static observation.

\section{Cell survival rate assay}

Cell Counting Kit-8 (CCK-8; Dojindo, Kumamoto, Japan) was used to evaluate the cell survival rate. Liver cancer cells were treated with $0.25 \%$ trypsin to form a cell suspension. We then added $90 \mu \mathrm{L}$ of the cell suspension (5,000 cells/ well) and $10 \mu \mathrm{L}$ of CCK- 8 to each well of a 96-well plate and allowed it to incubate for $4 \mathrm{~h}$. An enzyme mark instrument filter was used to measure the optical density (OD) at $450 \mathrm{~nm}$. 


\section{AO/EB staining}

Human HCC cells were seeded at $2 \times 10^{5}$ cells/dish in $35 \mathrm{~mm}$ cell culture dishes, incubated overnight at $37^{\circ} \mathrm{C}$ in an incubator with $95 \%$ air and $5 \% \mathrm{CO}_{2}$, and treated with different concentrations of $\mathrm{O}_{3}$ for $15 \mathrm{~min}$. Then, the $\mathrm{O}_{3}$ was removed and $1 \mathrm{~mL}$ of a 1:1 $\mathrm{AO} / \mathrm{EB}$ dye mixture was added to each dish. The cells were washed twice with PBS and examined under a fluorescence microscope.

\section{Annexin V-FITC/PI apoptosis assay kit}

Apoptosis of BEL7402 cells was evaluated using the Annexin V-FITC/PI apoptosis assay kit (Keygen Bio., Changchun, Jilin, China). After treatment with various concentrations of $\mathrm{O}_{3}$, cells were harvested, washed twice with PBS, and stained with V-FITC/PI for $15 \mathrm{~min}$. Then, the cells were washed twice with PBS and a flow cytometer (Becton, Dickinson, and Co., Biosciences, San Jose, CA, USA) was used to measure the rate of cell apoptosis. FlowJo software (https:// www.flowjo.com) was used to analyze the data.

\section{Mitochondrial membrane potential $(\Delta \Psi m)$ assay}

Mitochondrial depolarization was assessed by staining with 5, 5', 6,6'-tetrachloro-1, 1', 3,3'-tetraethyl benzimidazolecarbocyanine iodine (JC-1, Beyotime, Shanghai, China) and flow cytometry analysis. Briefly, cells were treated with various concentrations of $\mathrm{O}_{3}$, harvested, incubated with the JC-1 staining solution, and the ratio of green-fluorescent JC-1 monomers and red-fluorescent J-aggregates were assessed by flow cytometry. Mitochondrial depolarization was determined by the green/red fluorescence intensity ratio. The cells were examined using a fluorescence microscope.

\section{Western blot analysis}

The BEL7402 cells were lysed by radioimmunoprecipitation assay (RIPA) lysis buffer (Beyotime Institute of Biotechnology, Haimen, China), and the total proteins extracted for western blot analysis. A 12\% sodium dodecyl sulfate-polyacrylamide gel electrophoresis (SDS-PAGE) was used to separate $100 \mu \mathrm{g}$ of protein per lane and then transferred onto a nitrocellulose membrane (KGaA; Merck, Kenilworth, NJ, USA). Next, the membrane was blocked in $5 \%$ non-fat milk at room temperature for $1 \mathrm{~h}$, and incubated overnight at $4{ }^{\circ} \mathrm{C}$ with primary antibodies (dilution, 1:1,000; rat. Cell Signaling Technology, Inc., Danvers, MA, USA). After washing with tris-buffered saline with Tween 20 (TBST), the membranes were incubated with horseradish peroxidase (HRP)-conjugated secondary antibodies (dilution, 1:5,000; rat. Cell Signaling Technology, Inc.) at room temperature for $1 \mathrm{~h}$, and the protein bands detected by chemiluminescence (Fdbio Science, Hangzhou, Zhejiang, China).

\section{Detection of intracellular ROS}

Intracellular ROS levels were evaluated using 2,7-dichlorodihydrofluorescein diacetate (DCFH-DA, Beyotime, China) according to the manufacturer's instructions. Fluorescence intensities were detected by flow cytometry. The excitation wavelength was $488 \mathrm{~nm}$ and the emission wavelength was $525 \mathrm{~nm}$. Cell suspensions at a concentration of $1 \times 10^{6}$ cells $/ \mathrm{mL}$ were pre-treated with $1 \% 60 \mathrm{mM}$ NAC for 20 min then treated with $\mathrm{O}_{3}$. The CCK-8 (Dojindo, Japan) was used to evaluate inhibition of cell proliferation.

\section{Evaluation of the antitumor activity}

We obtained 6-week-old BALB/C mice from the Experimental Animal Center at Southern Medical University (Guangzhou, Guangdong, China) and raised them under standard laboratory conditions. After 1 week of adaptation, BEL7402 cells $\left(1 \times 10^{7} / 100 \mathrm{~mL}\right)$ were subcutaneously inoculated on the armpit of mice, and treatments were initiated when tumors had been successfully established (defined as day 0). Mice were randomly divided into two groups: intratumor injection (IT; $\mathrm{O}_{3}, 20 \mu \mathrm{g} / \mathrm{mL}, 0.2 \mathrm{~mL}$ ) and control (normal saline solution, $0.2 \mathrm{~mL}$ ). There were six mice in each group. Mice were injected every day for 10 days, and tumor volumes were recorded. After 21 days, the mice were anesthetized and anatomized, and tumor tissues were removed for histological examination by hematoxylin and eosin (H\&E) or immunohistochemical (IHC) staining. Briefly, tumor tissue sections were dewaxed and rehydrated by immersing the tissue in series concentrations of ethanol and xylene. After blocking with bovine serum albumin (BSA), sections were stained with terminal deoxynucleotidyl transferase dUTP nick and labeling (TUNEL, Peviva, West Chester, OH, USA), JNK (Cell Signaling Technology, Inc.) and Ki67 (Thermo Fisher Scientific, Waltham, MA, USA) primary antibodies and then probed with secondary peroxidase antibodies. The expression distribution of the TUNEL 
A

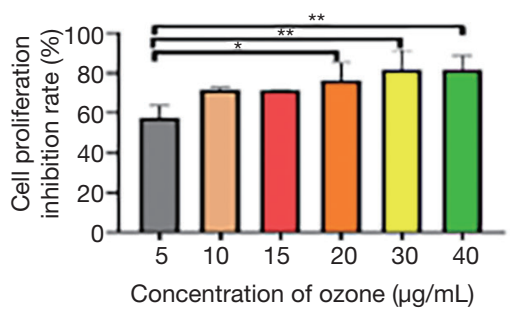

C
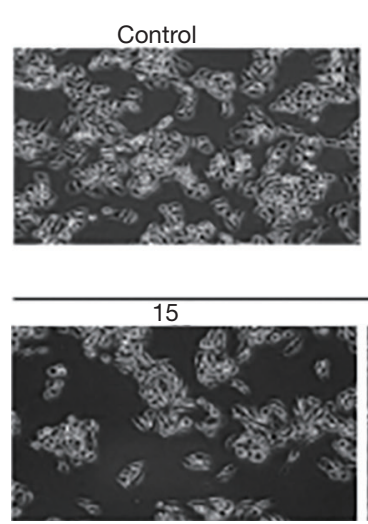

B
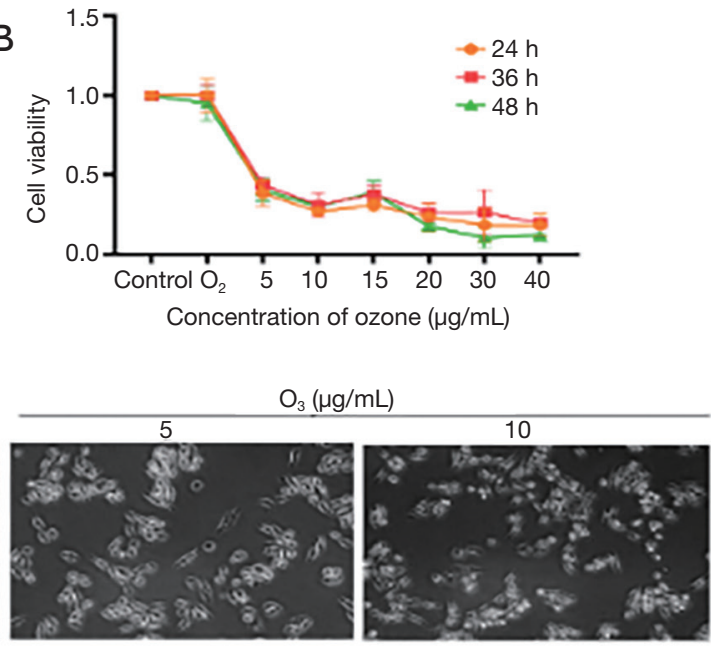

$\mathrm{O}_{3}(\mu \mathrm{g} / \mathrm{mL})$
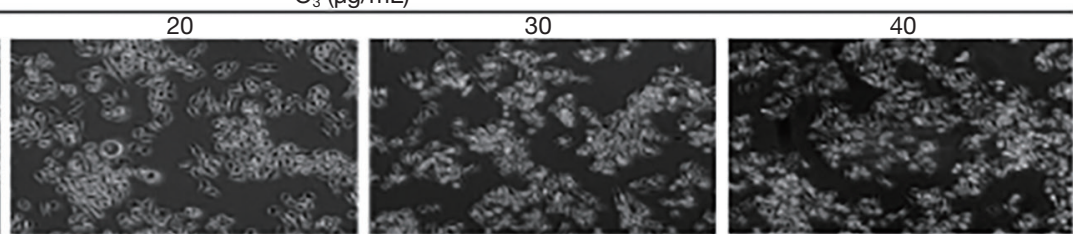

Figure $1 \mathrm{O}_{3}$ inhibits cell proliferation in BEL7402 cells. (A) BEL7402 cells were treated with 5, 10, 15, 20, 30, or 40 $\mu \mathrm{g} / \mathrm{mL} \mathrm{O}$ for 15 min, cultured for $24 \mathrm{~h}$, and cell viability was analyzed using the CCK-8 assay; (B) BEL7402 cells were treated with 5, 10, 15, 20, 30, or 40 $\mu$ g/mL $\mathrm{O}_{3}$ for $15 \mathrm{~min}$, cultured for 24,36 , or $48 \mathrm{~h}$, and cell viability was analyzed using the CCK-8 assay. Data are shown as the mean \pm SD of three independent experiments. The relationship between groups were assessed by one-way ANOVA with the Dunnett's test $\left(^{*}, \mathrm{P}<0.05\right.$; **, $\mathrm{P}<0.01$ ). (C) BEL7402 cells were treated with 5, 10, 15, 20, 30, $40 \mu \mathrm{g} / \mathrm{mL} \mathrm{O}_{3}$ for $15 \mathrm{~min}$, cultured for $24 \mathrm{~h}$, and then cell morphology was observed by microscopy (×100 magnification). $\mathrm{O}_{3}$, ozone; CCK-8, Cell Counting Kit-8; SD, standard deviation; ANOVA, analysis of variance.

apoptosis marker and Ki67 proliferation marker and the tissue necrosis was observed at different magnifications under light microscopy. A protocol was prepared before the study without registration. Experiments were performed under a project license (No.: NFYY-2019-84) granted by Southern Medical University. All animal experiments were performed in compliance with protocols approved by the Animal Care and Use Committee of the Southern Medical University.

\section{Statistical analysis}

Statistical analysis was performed with SPSS software version 19.0 (IBM Corp., Chicago, IL, USA) and GraphPad Prism 8.0 (GraphPad Software, La Jolla, CA, USA). All experiments were repeated three times, All data were presented as mean \pm standard deviation (SD). The differences between two groups were analyzed by two-tailed Student's $t$-test. The relationships between groups were assessed by one-way analysis of variance (ANOVA) with Dunnett's test. A P value $<0.05$ was considered statistically significant and a $\mathrm{P}$ value $<0.01$ was accepted as highly statistically significant $\left({ }^{*}, \mathrm{P}<0.05 ;{ }^{* *}, \mathrm{P}<0.01 ;{ }^{* * *}, \mathrm{P}<0.001 ;{ }^{* * * *}, \mathrm{P}<0.0001\right)$.

\section{Results}

\section{$\mathrm{O}_{3}$ inbibits BEL7402 cell proliferation}

To validate the cytotoxicity of $\mathrm{O}_{3}$ on human HCC cells, BEL7402 cells were treated with $5,10,15,20,30$, or $40 \mu \mathrm{g} / \mathrm{mL} \mathrm{O}_{3}$ for $15 \mathrm{~min}$, incubated for 24,36 , or $48 \mathrm{~h}$, and observed for cell morphologies. The cytotoxicity effect of $\mathrm{O}_{3}$ against BEL7402 cells was evaluated using the CCK-8 assay. The $\mathrm{O}_{3}$ showed concentration-dependent cell death as the cell viability decreased and the $\mathrm{O}_{3}$ dose increased, and the $\mathrm{IC}_{50}$ value was $4.867 \mu \mathrm{g} / \mathrm{mL}$ (Figure $1 A$ ). However, this observation did not depend on culture time (Figure 1B). 
A

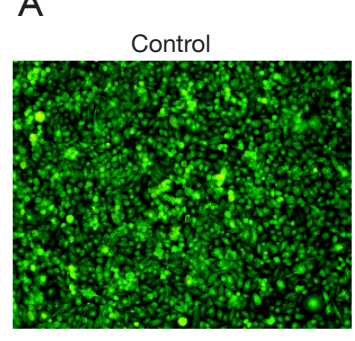

B

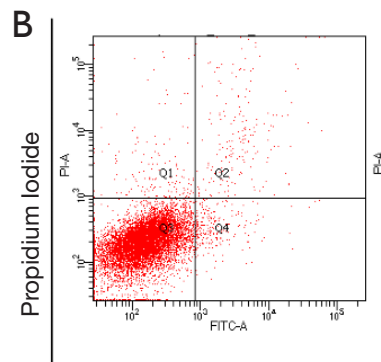

C

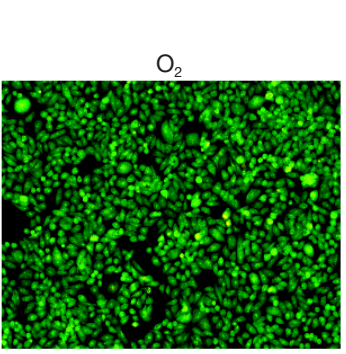

$\mathrm{O}_{3}(\mu \mathrm{g} / \mathrm{mL})$
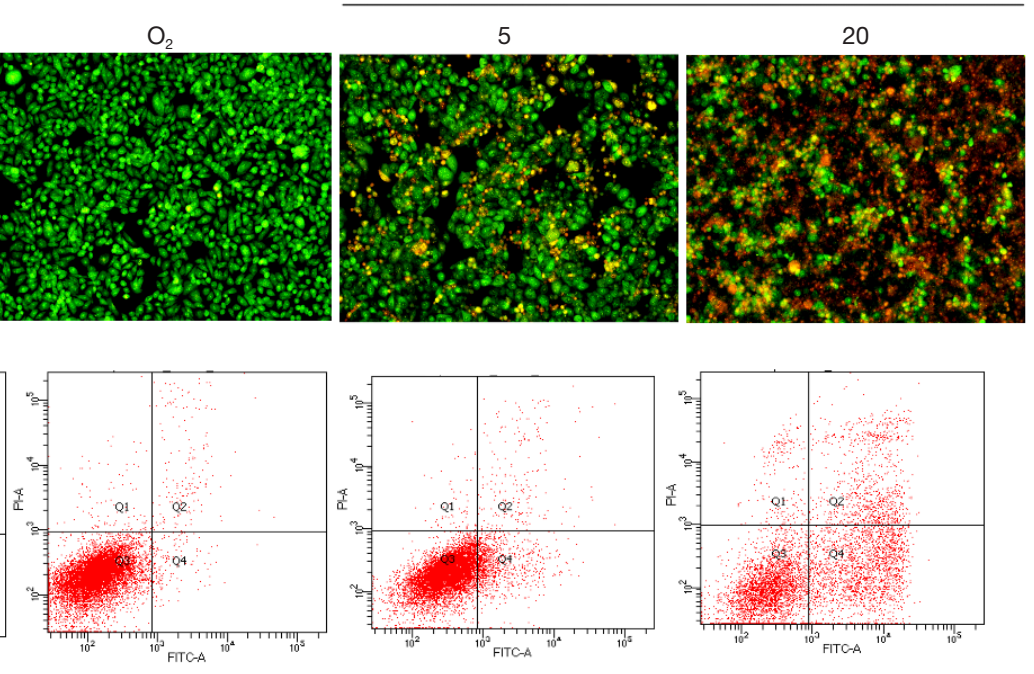

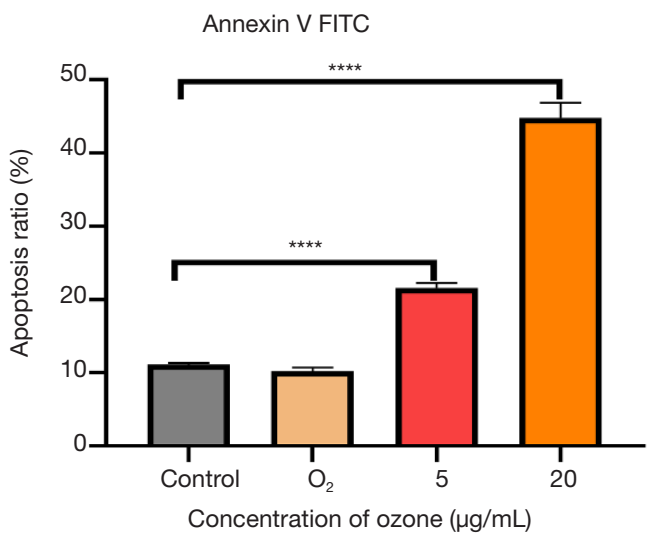

Figure $2 \mathrm{O}_{3}$ induces apoptosis of BEL7402 cells. (A) BEL7402 cells were treated with $\mathrm{O}_{3}, 5 \mu \mathrm{g} / \mathrm{mL} \mathrm{O}_{3}$, or $20 \mu \mathrm{g} / \mathrm{mL} \mathrm{O}$ for 15 min, cultured for $24 \mathrm{~h}$, stained with AO/EB, and examined by fluorescence microscopy (×100 magnification); (B) flow cytometry analysis of BEL7402 cell apoptosis after treatment with $\mathrm{O}_{3}, 5 \mu \mathrm{g} / \mathrm{mL} \mathrm{O}_{3}$, or $20 \mu \mathrm{g} / \mathrm{mL} \mathrm{O}_{3}$; (C) histogram of the percent of apoptotic cells after $\mathrm{O}_{3}$ treatment. Data are shown as the mean $\pm \mathrm{SD}$ of three independent experiments. The relationship between groups were assessed by one-way ANOVA with the Dunnett's test $\left.{ }^{* * * *}, \mathrm{P}<0.0001\right) . \mathrm{O}_{3}$, ozone; AO/EB, acridine orange/ethidium bromide; SD, standard deviation; ANOVA, analysis of variance.

We found that upon treatment with $\mathrm{O}_{3}$, BEL7402 cells became round and small with nuclear shrinkage and fragmentation and small fragments appeared in the culture dish (Figure 1C). These data suggest that $\mathrm{O}_{3}$ inhibits BEL7402 cell proliferation in a concentration-dependent manner.

\section{$\mathrm{O}_{3}$ induces apoptosis in BEL7402 cells}

During apoptosis, the nucleus condenses, the DNA fragments, and apoptotic bodies form, and these changes are detectable by AO/EB staining and flow cytometry. To confirm that $\mathrm{O}_{3}$ induced apoptosis in BEL7402 cells, nuclear morphological changes were observed by AO/ EB staining and fluorescence microscopy. Normal and undamaged cells have complete cell membranes that only $\mathrm{AO}$ can enter, and AO-stained cells emit green fluorescence. The EB can freely enter cells with damaged membranes, and EB-stained cells emit red fluorescence. We found that upon $\mathrm{O}_{3}$ treatment, the number of green-fluorescent cells decreased while the number of red/orange-fluorescent cells increased (Figure 2A). Annexin V-FITC/PI staining 


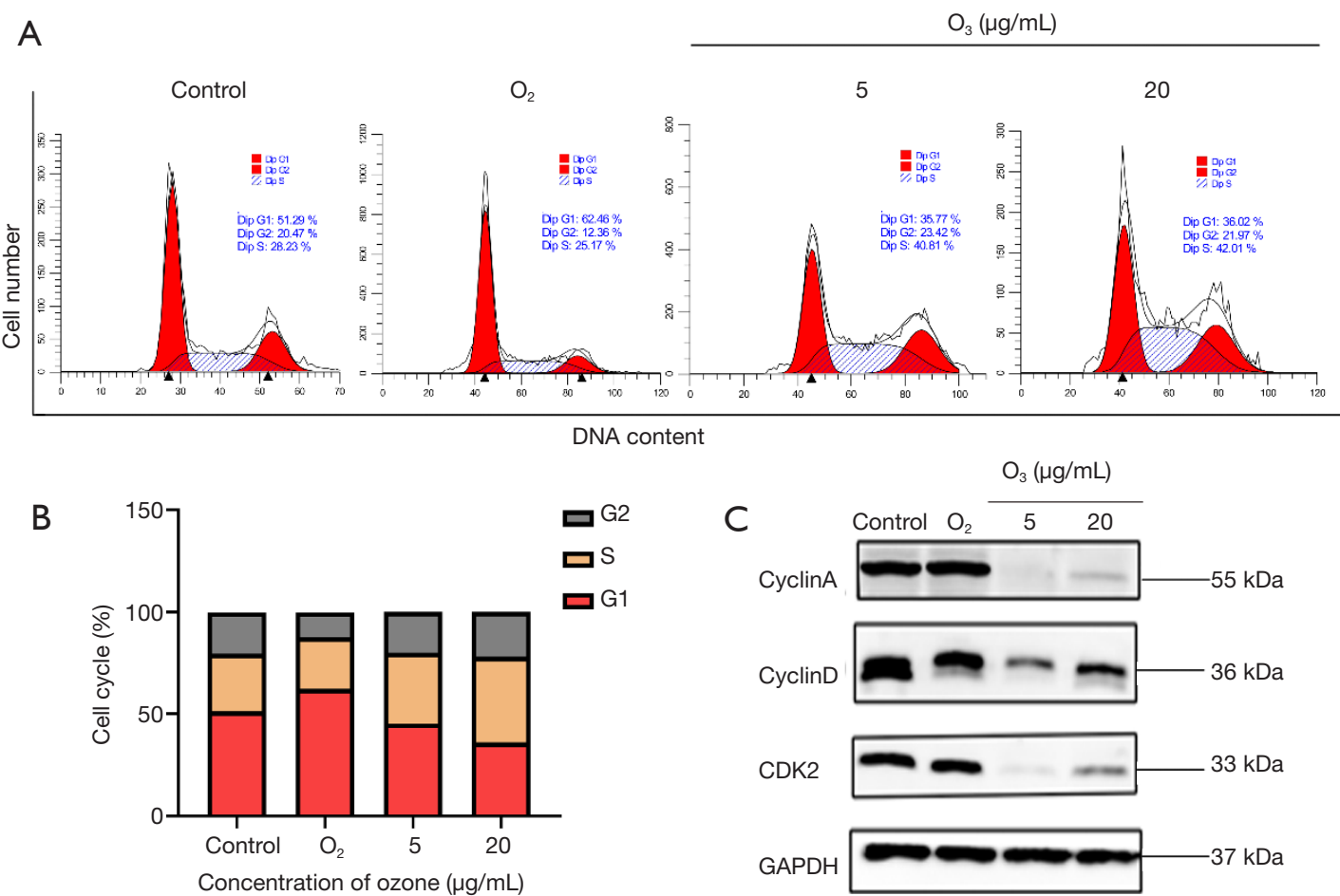

Figure $3 \mathrm{O}_{3}$ induces $\mathrm{S}$ phase cell cycle arrest in BEL7402 cells. (A,B) BEL7402 cells were treated with $\mathrm{O}_{2}, 5 \mu \mathrm{g} / \mathrm{mL} \mathrm{O}_{3}$, or $20 \mu \mathrm{g} / \mathrm{mL} \mathrm{O}_{3}$ for $15 \mathrm{~min}$, cultured for $24 \mathrm{~h}$, and cell cycle distribution was measured by flow cytometry. The cell cycle distribution data are presented graphically; (C) expression of cyclin A, cyclin D, and CDK2 was evaluated by western blot. GAPDH was used as the internal control. $\mathrm{O}_{3}$, ozone; GAPDH, glyceraldehyde 3-phosphate dehydrogenase.

was performed to determine the degree of apoptosis induced by $\mathrm{O}_{3}$. After treatment with $\mathrm{O}_{2}$ (control), $5 \mu \mathrm{g} / \mathrm{mL}$ $\mathrm{O}_{3}$, or $20 \mu \mathrm{g} / \mathrm{mL} \mathrm{O}_{3}$, the number of apoptotic cells were measured by flow cytometry, which revealed that $\mathrm{O}_{3}$-induced apoptosis increased in a concentrationdependent manner. Flow cytometry showed that the sum of the early and late apoptotic cell populations increased from $2.4 \%$ to $82.1 \%$ upon treatment with increasing concentrations of $\mathrm{O}_{3}$ (Figure 2B,2C). These data indicated that $\mathrm{O}_{3}$ inhibits cell proliferation via cell apoptosis.

\section{$\mathrm{O}_{3}$ induces $S$ phase cell cycle arrest in BEL7402 cells}

We investigated the distribution of cell cycle and cell cycle-related proteins to determine whether $\mathrm{O}_{3}$ inhibits cell proliferation via cell cycle arrest. The data showed that treatment with 5 or $20 \mu \mathrm{g} / \mathrm{mL} \mathrm{O}_{3}$ for $24 \mathrm{~h}$ led to an accumulation of cells in the $\mathrm{S}$ and $\mathrm{G} 2$ phases (Figure $3 A, 3 B$ ). The proportion of BEL7402 S phase cells increased from
$28.23 \%$ in the control group to $42.01 \%$ in the $\mathrm{O}_{3}$ treatment group, which was a 1.5 -fold increase. In addition, treatment with 5 and $20 \mu \mathrm{g} / \mathrm{mL} \mathrm{O}_{3}$ reduced cyclin A/D and CDK2 expression (Figure 3C). Thus, we concluded $\mathrm{O}_{3}$ inhibits BEL7402 cell proliferation via $S$ phase arrest.

\section{Changes in the $\Delta \Psi m$}

Changes in the $\Delta \Psi \mathrm{m}$ were determined by JC-1 staining. Low membrane potential is represented by greenfluorescent JC-1 monomers and high membrane potential is represented by red-fluorescent J-aggregates. Mitochondrial depolarization is determined by the green/red fluorescence intensity ratio. We found that cells in the control and oxygen-treated groups were yellow-green, whereas cells in the $\mathrm{O}_{3}$ group were green. When cells were treated with 5 and $20 \mu \mathrm{g} / \mathrm{mL} \mathrm{O}_{3}$, green fluorescence increased from 3.12\% to $46.6 \%$, and red fluorescence decreased from $79.3 \%$ to $43.3 \%$ (Figure 4). These results suggested that $\mathrm{O}_{3}$ lowers 

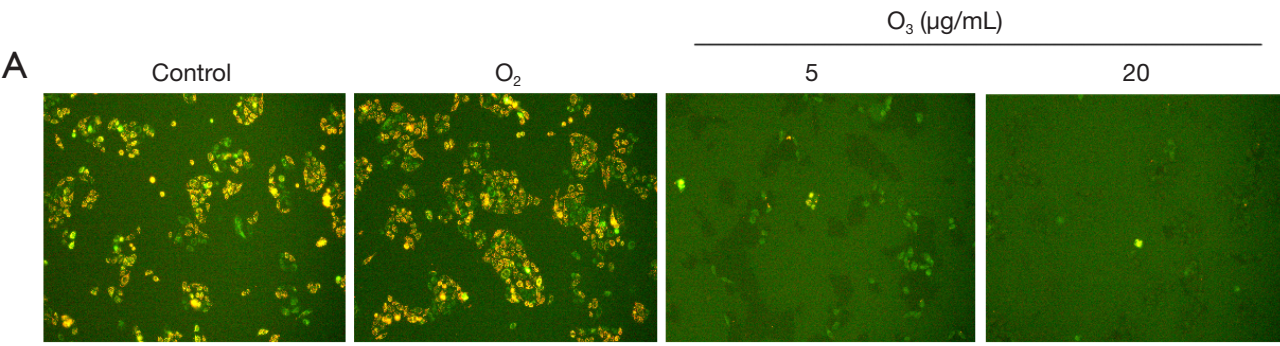

B
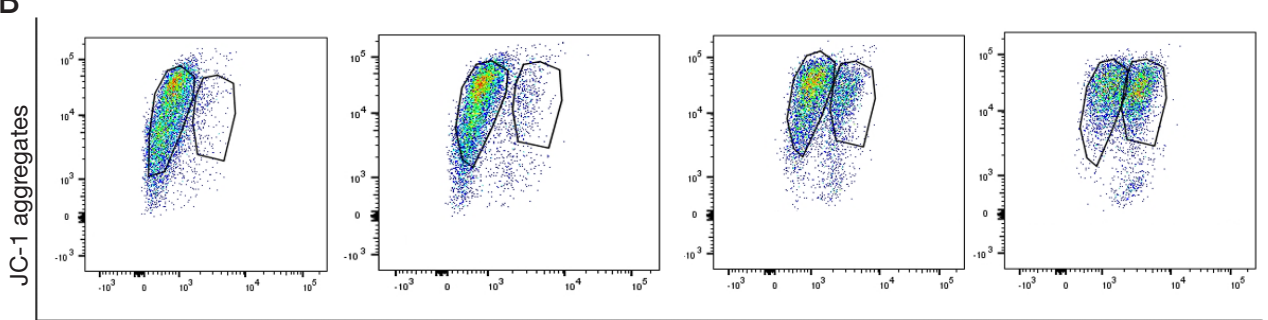

JC-1 monomers

C

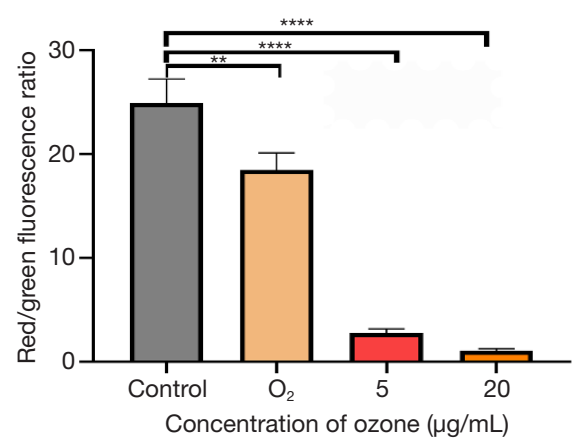

Figure $4 \mathrm{O}_{3}$ reduces the membrane potential. (A) BEL7402 cells were treated with $\mathrm{O}_{2}, 5 \mu \mathrm{g} / \mathrm{mL} \mathrm{O}$, or $20 \mu \mathrm{g} / \mathrm{mL} \mathrm{O}$ for $15 \mathrm{~min}$, cultured for $24 \mathrm{~h}$, and the $\Delta \Psi \mathrm{m}$ was measured by JC-1 probe labeling and fluorescence microscopy ( $\times 100$ magnification); (B,C) the labeled cells were also analyzed by flow cytometry, and the flow cytometry data are presented graphically. Data are shown as the mean \pm SD of independent experiments, The relationship between groups were assessed by one-way ANOVA with the Dunnett's test $\left({ }^{* *}, \mathrm{P}<0.01 ;{ }^{* * * *}, \mathrm{P}<0.0001\right)$. $\mathrm{O}_{3}$, ozone; $\Delta \Psi \mathrm{m}$, mitochondrial membrane potential; SD, standard deviation; ANOVA, analysis of variance.

the $\Delta \Psi \mathrm{m}$ in a concentration-dependent manner.

\section{$\mathrm{O}_{3}$ induces mitochondrial-related apoptosis in BEL7402 cells}

After induction of apoptosis upon $\mathrm{O}_{3}$ treatment was confirmed, western blotting was performed to detect expression of apoptosis-related proteins. The BEL7402 cells were treated with $\mathrm{O}_{2}$ or 0,5 , or $20 \mu \mathrm{g} / \mathrm{mL} \mathrm{O}_{3}$. The B-cell lymphoma 2 (BCL-2) protein levels decreased significantly in BEL7402 cells treated with 5 or $20 \mu \mathrm{g} / \mathrm{mL}$ $\mathrm{O}_{3}$, and the BCL-2-associated $\mathrm{X}$ protein $(\mathrm{BAX}) / \mathrm{BCL}-2$ ratio increased in cells treated with $5 \mu \mathrm{g} / \mathrm{mL} \mathrm{O}_{3}$. Consistent with these results, cytochrome $\mathrm{C}(\mathrm{Cyt}-\mathrm{C})$ and cleaved pro- caspase-9 levels also increased, and cleaved poly ADPribose polymerase (PARP) levels decreased (Figure $5 A, 5 B$ ). To determine the effect of $\mathrm{O}_{3}$ on the MAPK pathway, p-JNK levels were evaluated, which revealed that p-JNK levels increased in cells treated with $\mathrm{O}_{3}$ (Figure 5C).

\section{$\mathrm{O}_{3}$ boosts ROS generation in BEL702 cells}

As a decrease in the membrane potential is usually accompanied by ROS production, we measured ROS levels in $\mathrm{O}_{3}$-treated cells, and as expected, we found an increase in ROS levels upon $\mathrm{O}_{3}$ treatment (Figure 6). Furthermore, we also observed a reversal in the inhibition of cell proliferation in cells pre-treated with $\mathrm{N}$-acetylcysteine (NAC). We 


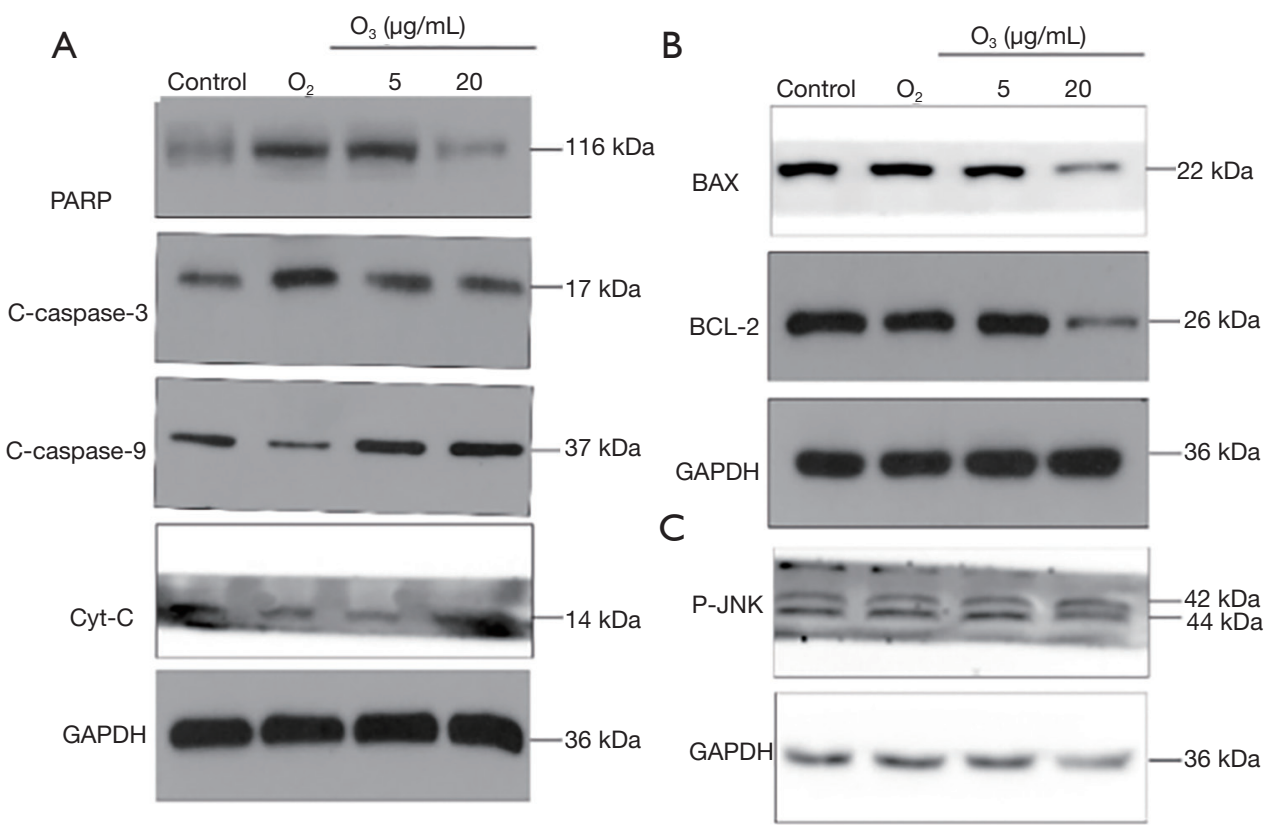

Figure $5 \mathrm{O}_{3}$ induces expression of proteins involved in apoptosis in BEL7402 cells. (A,B) BEL7402 cells were treated with $\mathrm{O}_{2}, 5 \mu \mathrm{g} / \mathrm{mL} \mathrm{O}_{3}$, or $20 \mu \mathrm{g} / \mathrm{mL} \mathrm{O}_{3}$ for $15 \mathrm{~min}$, cultured for $24 \mathrm{~h}$, and Cyt-C, C-caspase-9, C-caspase-3, PARP, BAX, BCL-2, and (C) p-JNK protein levels were measured by western blot. GAPDH was used as the internal control. $\mathrm{O}_{3}$, ozone; Cyt-C, cytochrome C; BAX, BCL-2-associated X protein; BCL-2, B-cell lymphoma 2; GAPDH, glyceraldehyde 3-phosphate dehydrogenase.

speculate that ROS is necessary for $\mathrm{O}_{3}$-induced apoptosis.

\section{Evaluation of $\mathrm{O}_{3}$ antitumor activity in a mouse model}

To investigate antitumor activity of $\mathrm{O}_{3}$ in vivo, tumor volumes were measured for 21 days after intratumor injection. There were five mice left in the control group, as one mouse died during the experiment. A total of four mice remained in the IT group, as two mice died of pneumothorax after intratumor injection. Tumor volume increased significantly over time in the control group, but growth was delayed by intratumor injection $\mathrm{O}_{3}(20 \mu \mathrm{g} / \mathrm{mL})$. there was no statistically significant difference between the two groups on days 0,7 , and $14(\mathrm{P}>0.05)$, but there was a statistically significant difference between the two groups on days 17 and $21(\mathrm{P}<0.05)$ (Figure 7). The TUNEL assay showed that cell apoptosis significantly increased in the IT group compared with the control group (Figure 7). The expression of ki67 in the IT group was significantly decreased compared with the control group, and the degree of tumor necrosis increased in IT group compared with the control group (Figure 8). The expression of JNK in the IT group was significantly increased compared with the control group (Figure 9). Pneumothorax may be induced by intratumor injection, it is therefore recommended that the injection is guided by B ultrasound.

\section{Discussion}

$\mathrm{O}_{3}$ is an allotrope of oxygen with a half-life of $40 \mathrm{~min}$ at $20{ }^{\circ} \mathrm{C}$ that decomposes spontaneously (15). It causes lipid peroxidation of the cell membrane, oxidation of proteins, inactivation of enzymes, and destruction of DNA by producing free radicals and inducing oxidative stress. It immediately reacts with antioxidants, polyunsaturated fatty acids (PUFAs), proteins, and carbohydrates in a physiological environment causing the formation of ROS, lipid ozonation products (LOPs), and a variety of oxidized antioxidants (16).

Apoptosis is a type of programmed cell death that includes the intrinsic pathway (also called the mitochondrial pathway) and the extrinsic pathway (also called the death receptor pathway) (17). The intrinsic pathway is activated by release of Cyt-C from mitochondria, whereas the extrinsic pathway is mediated by TRAILR and FAS death receptors. Both pathways activate a series of proteases, 

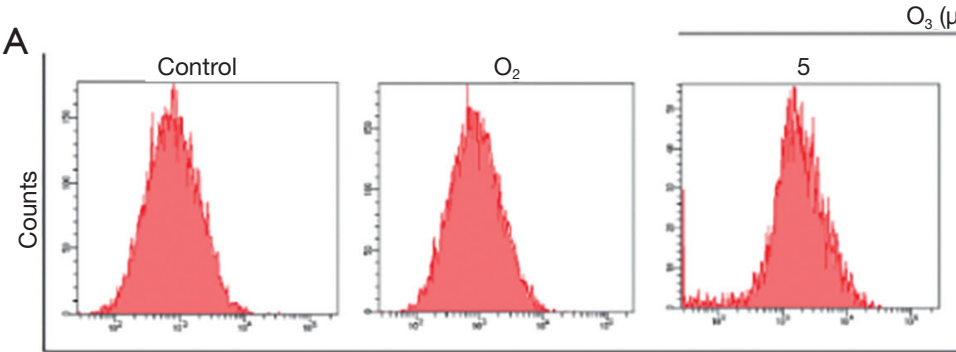

$\mathrm{O}_{3}(\mu \mathrm{g} / \mathrm{mL})$

DCF Fluorescence Intensity

B
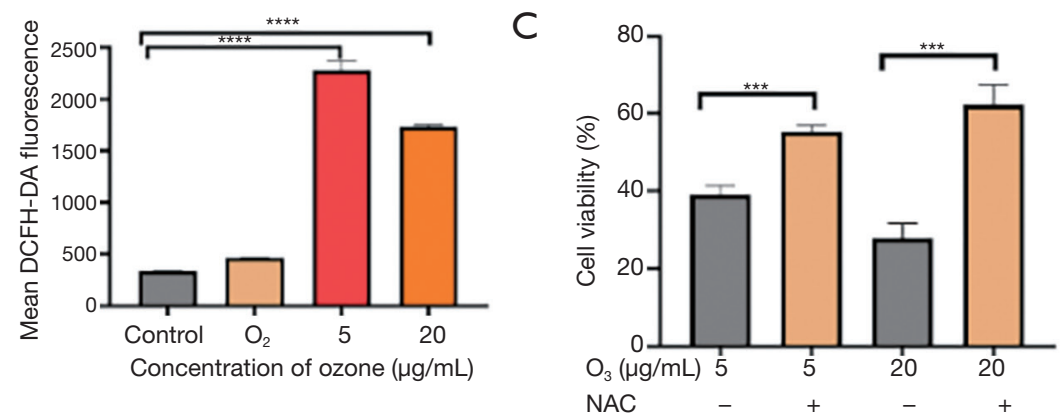

Figure $6 \mathrm{O}_{3}$ induces intracellular ROS production in BEL7402 cells. (A,B) BEL7402 cells were treated with $\mathrm{O}_{2}, 5 \mu \mathrm{g} / \mathrm{mL} \mathrm{O}_{3}$, or $20 \mu \mathrm{g} / \mathrm{mL}$ $\mathrm{O}_{3}$ for $15 \mathrm{~min}$, cultured for $24 \mathrm{~h}$, and intracellular ROS levels were evaluated by flow cytometry. Flow cytometry data are shown graphically; (C) cells were pre-treated with NAC and the inhibition of cell proliferation was analyzed using the CCK-8 assay. Data are shown as the mean \pm SD of 3 independent experiments, The relationship between groups were assessed by one-way ANOVA with the Dunnett's test (***, $\mathrm{P}<0.001$; ***, $\mathrm{P}<0.0001) . \mathrm{O}_{3}$, ozone; ROS, reactive oxygen species; NAC, N acetylcysteine; CCK-8, Cell Counting Kit-8; SD, standard deviation; ANOVA, analysis of variance

including caspase- $3,-6,-7,-8,-9$, and-10, resulting in cell death (18). The extrinsic apoptosis pathway is initiated by caspase-8, which activates a downstream cascade of reactions (19), whereas the intrinsic pathway is triggered by intracellular stimuli via the BCL-2 protein family $(20,21)$. The BCL-2 family is composed of pro-apoptotic proteins and antiapoptotic proteins that regulate apoptosis and the survival and proliferation of cancer cells (22). In this study, we found that Cyt-C, PARP, caspase-9, and caspase- 3 expression was higher in the $5 \mu \mathrm{g} / \mathrm{mL} \mathrm{O}_{3}$ group than in the control group. We also found that BCL-2 and cleaved caspase-8 expression were significantly lower in the $20 \mu \mathrm{g} / \mathrm{mL} \mathrm{O}_{3}$ group than in the control group. Thus, $\mathrm{O}_{3}$ may promote the death of liver cancer cells through both the intrinsic and extrinsic pathways of apoptosis.

It has been shown that the MAPK/JNK pathway associates closely with apoptosis (23). The MAPK signaling pathways, which include ERK, JNK, and p38 proteins, play important roles in chemically induced cell cycle arrest and apoptosis. The JNK and p38 MAPKs are activated by stress (24). To determine whether $\mathrm{O}_{3}$-induced apoptosis is associated with the MAPK/JNK pathway, the expression level of p-JNK was evaluated by western blot. We found that p-JNK expression increased significantly upon treatment with $\mathrm{O}_{3}$, thus $\mathrm{O}_{3}$ may induce apoptosis by activating JNK.

The ROS plays a crucial role in tumorigenesis, and accumulating evidence suggests that excessive ROS production directly damages DNA leading to apoptosis (25). It has been demonstrated that p38 MAPK and JNK activation mediates ROS-induced apoptosis $(26,27)$. The cytotoxicity of copper complexes derives from the generation of ROS driven by the metal. It has been shown that ROS also plays a significant role in activation of apoptosis by radiotherapy and chemotherapy $(28,29)$. Resveratrol induces cell cycle arrest and caspase-3, caspase-9, and PARP activation by inducing ROS production in $\mathrm{BC}$ cells, thereby enhancing sorafenibmediated apoptosis (30). Thus, ROS plays a complex role in tumor development and death. At low and medium concentrations, ROS can function as a signaling molecule that promotes the occurrence and development of cancer 


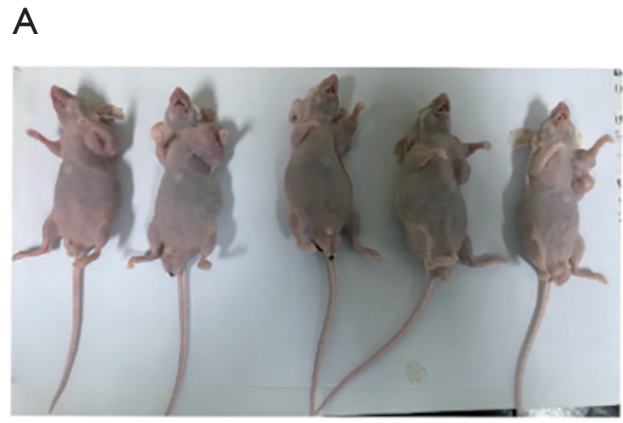

B
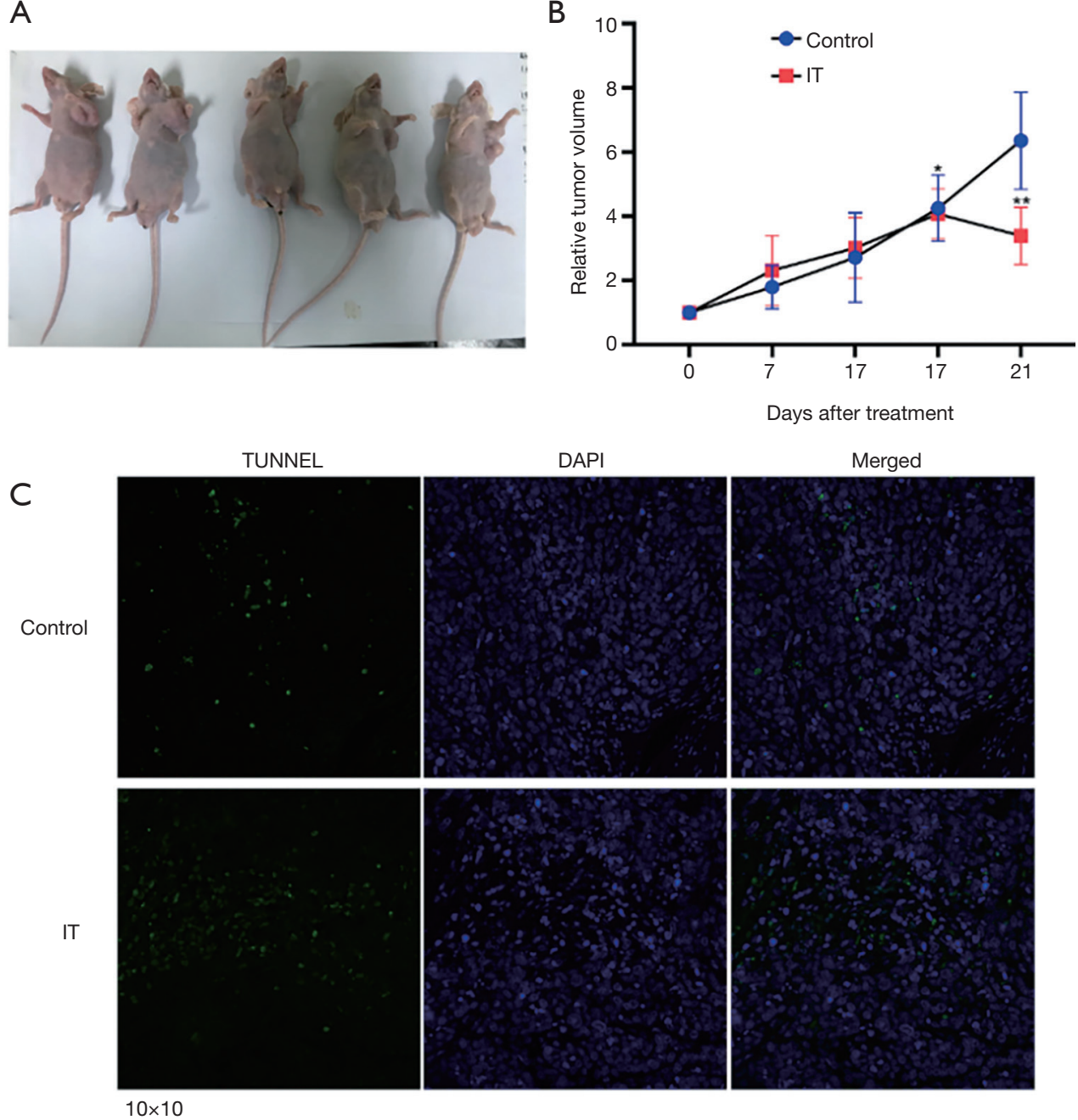

Figure 7 Antitumor effects in HCC model. (A) HCC model; (B) changes of tumor volume $\left({ }^{*}, \mathrm{P}<0.05\right.$; $\left.{ }^{* *}, \mathrm{P}<0.01\right)$; (C) TUNEL assay to determine apoptosis cell in tumor tissues. HCC, hepatocellular carcinoma; TUNEL, terminal deoxynucleotidyl transferase dUTP nick and labeling; IT, intratumor injection.

cells by inducing DNA mutations and genomic instability. On the other hand, at high concentrations, ROS increases oxidative stress leading to the damage of DNA, proteins, and lipids and resulting in cell apoptosis or death (31). It has been shown that isoleucine and roe protein hydrolysates from giant grouper fish induce ROS generation, leading to apoptosis (32). Resveratrol enhances the anticancer activity of etoposide through ROS-induced MAPK activation (33). Resveratrol also enhances erlotinib-induced apoptosis by increasing oxidative stress, ROS-dependent DNA damage, p53, PUMA, and cleaved caspase- 3 protein levels and by inhibiting expression of antiapoptotic proteins, thereby sensitizing lung cancer cells to chemotherapy (34).
Curcumin enhances the anticancer activity of irinotecan by inducing ROS production and activation of endoplasmic reticulum stress pathways in colon cancer cells (35). In this study, we found that ROS production was significantly higher in the $5 \mu \mathrm{g} / \mathrm{mL} \mathrm{O}_{3}$ group than in the control group. Furthermore, we showed that NAC, an ROS scavenger, reduced ROS production and reversed the inhibition of cell proliferation. Our data suggests that $\mathrm{O}_{3}$ induces ROS accumulation leading to BEL7402 cell death. Some Studies have showed that Fluoride promotes the accumulation of ROS by inhibiting the activity of antioxidant enzymes, resulting in the excessive production of ROS at the cellular level which further leads to activation of cell death processes 

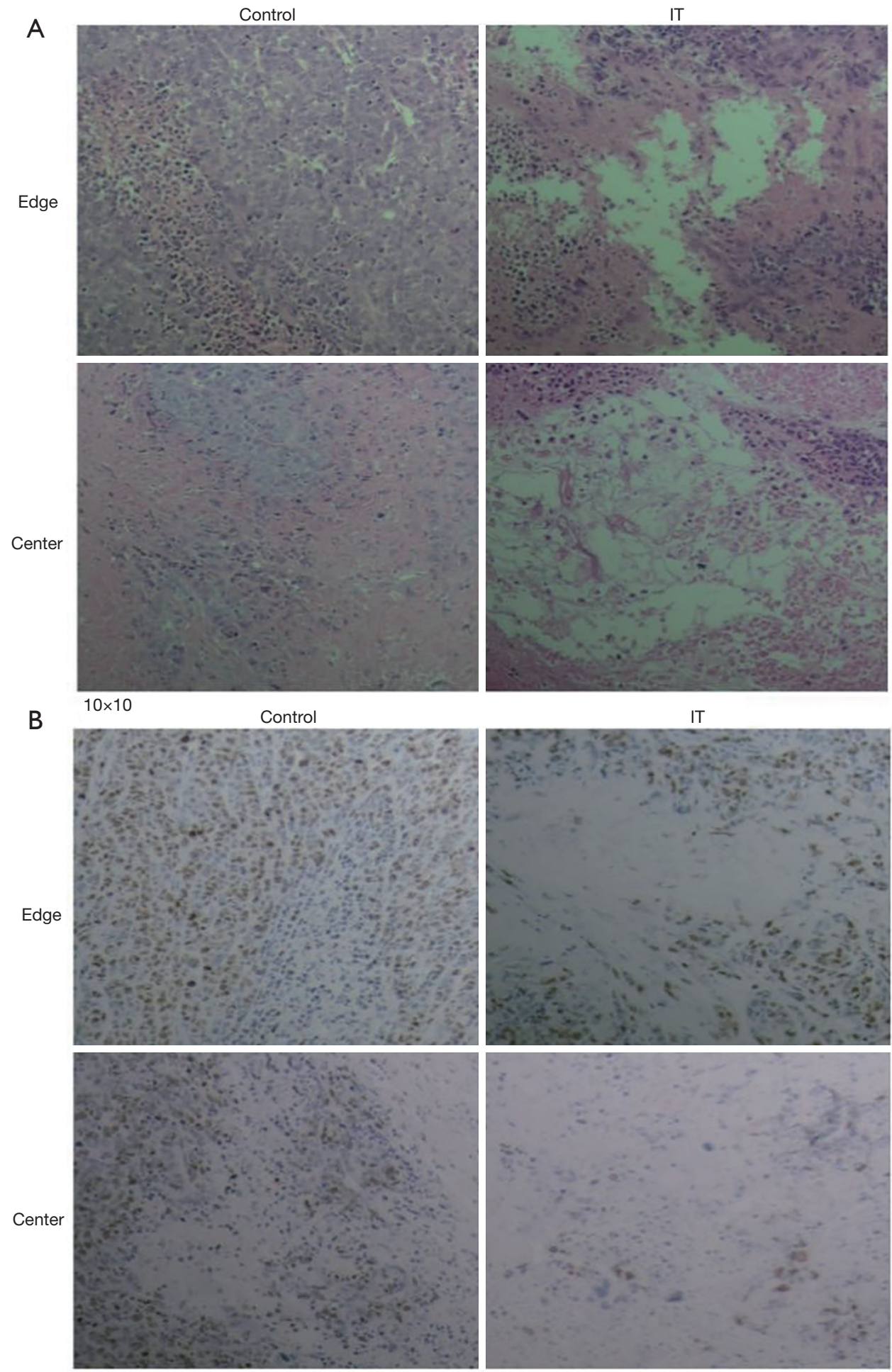

$10 \times 10$

Figure 8 Antitumor effects in HCC model. (A) The HCC histological change was examined with light microscope after H\&E staining; (B) immunofluorescence staining analysis of Ki67 in tumor tissues. HCC, hepatocellular carcinoma; H\&E, hematoxylin and eosin; IT, intratumor injection. 


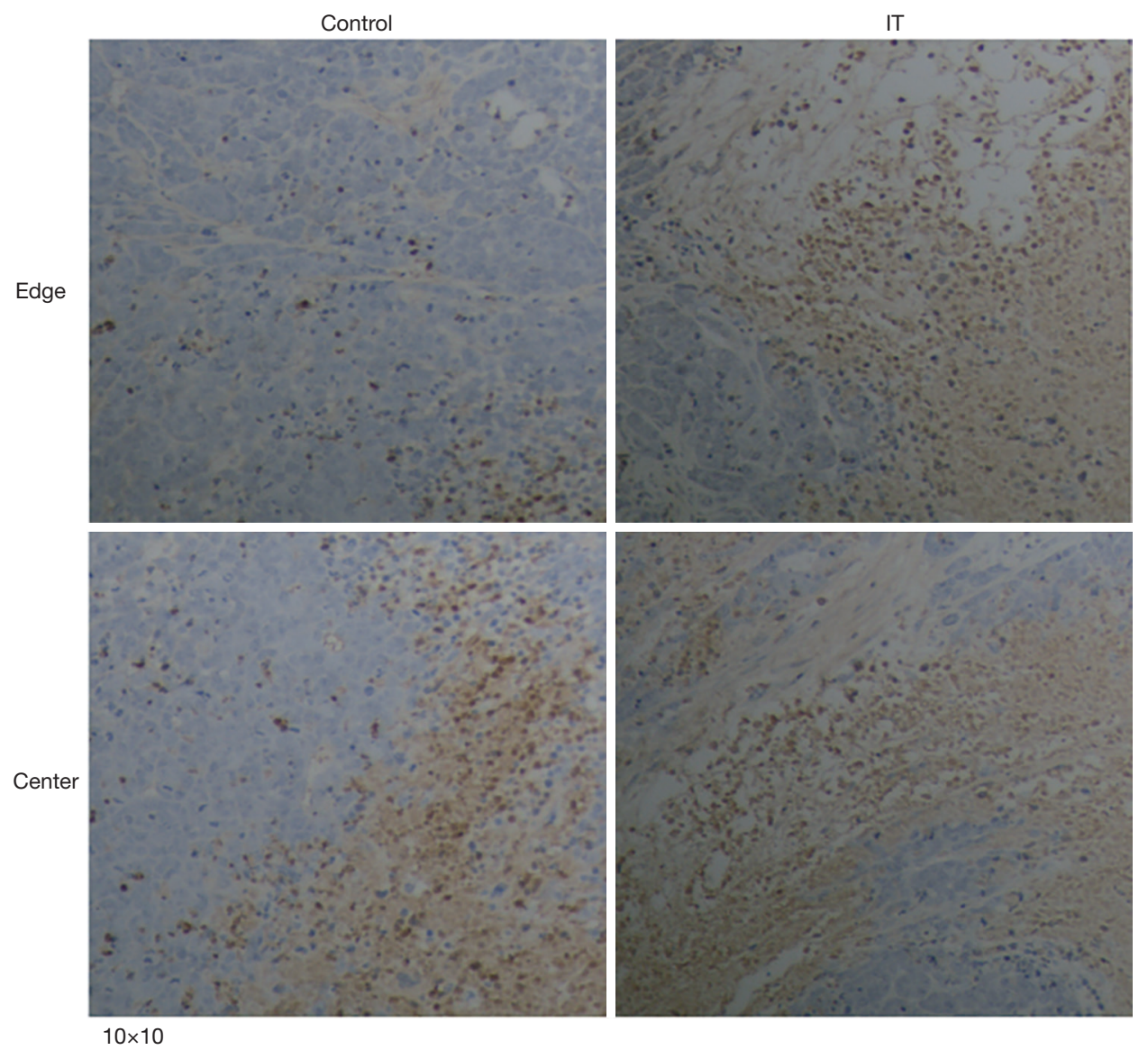

Figure 9 Antitumor effects in HCC model. Immunofluorescence staining analysis of JNK in tumor tissues. HCC, hepatocellular carcinoma.

such as apoptosis (36). In this article, we proved that the excessive production of ROS induced apoptosis. We pretreat cells with antioxidants, apoptosis decreased (Figure 6), so we think that Apoptosis is related to oxidative stress. This result in accordance with most research results.

Due to the decomposition product of $\mathrm{O}_{3}$ being oxygen, $\mathrm{O}_{3}$ is safe for cancer therapy. In addition, $\mathrm{O}_{3}$ gas is a novel, effective, and inexpensive cancer therapeutic. However, $\mathrm{O}_{3}$ is an extremely unstable gas, thus timely preparation and use of $\mathrm{O}_{3}$ gas in experiments is difficult, but critical for accurate experimental results; to ensure accurate results, repeated experiments are required. In clinical practice, because tumor cells are located in the body, it is difficult to administer $\mathrm{O}_{3}$ to directly target tumor cells. The $\mathrm{O}_{3}$ delivery method for direct cytotoxic action needs to be studied further. Interventional therapy may be a good way.

In this study, we explored the molecular mechanism of the antitumor effect of $\mathrm{O}_{3}$ on HCC. In vitro, $\mathrm{O}_{3}$ inhibited proliferation of BEL7402 cells. In addition, $\mathrm{O}_{3}$-induced cell cycle arrest and apoptosis were found to be mediated by ROS production. $\mathrm{O}_{3}$ treatment induced mitochondrial apoptosis and $\mathrm{S}$ phase cell cycle arrest through JNK signaling. Thus, the antitumor effect of $\mathrm{O}_{3}$ may be mediated by the ROS-modulated JNK pathway. In vivo, treatment with intratumor injection $\mathrm{O}_{3}(20 \mu \mathrm{g} / \mathrm{mL})$ inhibited HCC growth. In all, $\mathrm{O}_{3}$ inhibited $\mathrm{HCC}$ growth by increasing ROS production and activating the intrinsic apoptosis pathway (Figure 10). Thus, $\mathrm{O}_{3}$ has potential as an anticancer agent 


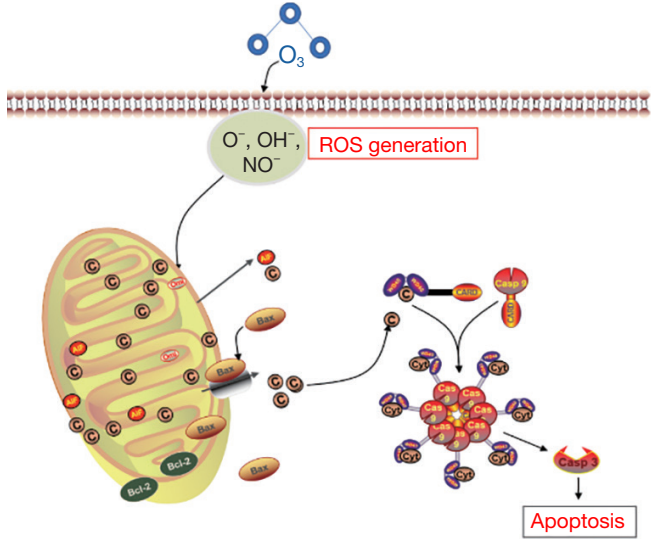

Figure 10 A schematic model of the mechanism indicating how $\mathrm{O}_{3}$ induces BEL7402 cell apoptosis. $\mathrm{O}_{3}$, ozone.

and may be used as a new and effective treatment for HCC.

\section{Acknowledgments}

Funding: The study was supported by the Dean Fund of Nanfang Hospital, Southern Medical University (2017B016) and the Industrial Technology Research and Development Funds (K1050215).

\section{Footnote}

Reporting Checklist: The authors have completed the ARRIVE reporting checklist. Available at https://dx.doi. org/10.21037/atm-21-3233

Data Sharing Statement: Available at https://dx.doi. org/10.21037/atm-21-3233

Conflicts of Interest: All authors have completed the ICMJE uniform disclosure form (available at https://dx.doi. org/10.21037/atm-21-3233). The authors have no conflicts of interest to declare.

Ethical Statement: The authors are accountable for all aspects of the work in ensuring that questions related to the accuracy or integrity of any part of the work are appropriately investigated and resolved. A protocol was prepared before the study without registration. Experiments were performed under a project license (No.: NFYY-201984) granted by Southern Medical University. All animal experiments were performed in compliance with protocols approved by the Animal Care and Use Committee of the Southern Medical University.

Open Access Statement: This is an Open Access article distributed in accordance with the Creative Commons Attribution-NonCommercial-NoDerivs 4.0 International License (CC BY-NC-ND 4.0), which permits the noncommercial replication and distribution of the article with the strict proviso that no changes or edits are made and the original work is properly cited (including links to both the formal publication through the relevant DOI and the license). See: https://creativecommons.org/licenses/by-nc-nd/4.0/.

\section{References}

1. Sung H, Ferlay J, Siegel RL, et al. Global cancer statistics 2020: GLOBOCAN estimates of incidence and mortality worldwide for 36 cancers in 185 countries. CA Cancer J Clin 2021;71:209-49.

2. Schmidt S, Follmann M, Malek N, et al. Critical appraisal of clinical practice guidelines for diagnosis and treatment of hepatocellular carcinoma. J Gastroenterol Hepatol 2011;26:1779-86.

3. Zhu F, Rhim H. Thermal ablation for hepatocellular carcinoma: what's new in 2019. Chin Clin Oncol 2019;8:58.

4. Arizumi T, Ueshima K, Iwanishi M, et al. The overall survival of patients with hepatocellular carcinoma correlates with the newly defined time to progression after transarterial chemoembolization. Liver Cancer 2017;6:227-35.

5. Llovet JM, Ricci S, Mazzaferro V, et al. Sorafenib in advanced hepatocellular carcinoma. N Engl J Med 2008;359:378-90.

6. Chen JH, Liu X, Chen K, et al. Sorafenib with or without concurrent transarterial chemoembolization in hepatocellular carcinoma: a cautionary comment of STAH trial. Transl Cancer Res 2020;9:400-1.

7. Morise Z, Kawabe N, Tomishige H, et al. Recent advances in liver resection for hepatocellular carcinoma. Front Surg 2014;1:21.

8. Wei CY, Chen PC, Chau GY, et al. Comparison of prognosis between surgical resection and transarterial chemoembolization for patients with solitary huge hepatocellular carcinoma. Ann Transl Med 2020;8:238.

9. Scassellati C, Galoforo AC, Bonvicini C, et al. Ozone: a 
natural bioactive molecule with antioxidant property as potential new strategy in aging and in neurodegenerative disorders. Ageing Res Rev 2020;63:101138.

10. Simonetti V, Quagliariello V, Giustetto P, et al. Association of ozone with 5-fluorouracil and cisplatin in regulation of human colon cancer cell viability: in vitro antiinflammatory properties of ozone in colon cancer cells exposed to lipopolysaccharides. Evid Based Complement Alternat Med 2017;2017:7414083.

11. Sweet F, Kao MS, Lee SC, et al. Ozone selectively inhibits growth of human cancer cells. Science 1980;209:931-3.

12. Karlic H, Kucera H, Metka M, et al. Effect of ozone and ionizing radiation on an in vitro model--a pilot study of 4 gynecologic tumors. Strahlenther Onkol 1987;163:37-42.

13. Cannizzaro A, Verga Falzacappa CV, Martinelli M, et al. $\mathrm{O}(2 / 3)$ exposure inhibits cell progression affecting cyclin B1/cdk1 activity in SK-N-SH while induces apoptosis in SK-N-DZ neuroblastoma cells. J Cell Physiol 2007;213:115-25.

14. Kuroda K, Yamashita M, Murahata Y, et al. Use of ozonated water as a new therapeutic approach to solve current concerns around antitumor treatment. Exp Ther Med 2018;16:1597-602.

15. Di Mauro R, Cantarella G, Bernardini R, et al. The biochemical and pharmacological properties of ozone: the smell of protection in acute and chronic diseases. Int J Mol Sci 2019;20:634.

16. Bocci V, Borrelli E, Travagli V, et al. The ozone paradox: ozone is a strong oxidant as well as a medical drug. Med Res Rev 2009;29:646-82.

17. Fernald K, Kurokawa M. Evading apoptosis in cancer. Trends Cell Biol 2013;23:620-33.

18. Ghobrial IM, Witzig TE, Adjei AA. Targeting apoptosis pathways in cancer therapy. CA Cancer J Clin 2005;55:178-94.

19. Fianco G, Contadini C, Ferri A, et al. Caspase-8: a novel target to overcome resistance to chemotherapy in glioblastoma. Int J Mol Sci 2018;19:3798.

20. Zaman S, Wang R, Gandhi V. Targeting the apoptosis pathway in hematologic malignancies. Leuk Lymphoma 2014;55:1980-92.

21. Schenk RL, Strasser A, Dewson G. BCL-2: Long and winding path from discovery to therapeutic target. Biochem Biophys Res Commun 2017;482:459-69.

22. Burz C, Berindan-Neagoe I, Balacescu O, et al. Apoptosis in cancer: key molecular signaling pathways and therapy targets. Acta Oncol 2009;48:811-21.

23. Guan FY, Gu J, Li W, et al. Compound K protects pancreatic islet cells against apoptosis through inhibition of the AMPK/JNK pathway in type 2 diabetic mice and in MIN6 $\beta$-cells. Life Sci 2014;107:42-9.

24. Yang JI, Tang JY, Liu YS, et al. Roe protein hydrolysates of giant grouper (epinephelus lanceolatus) inhibit cell proliferation of oral cancer cells involving apoptosis and oxidative stress. Biomed Res Int 2016;2016:8305073.

25. Teng JF, Mei QB, Zhou XG, et al. Polyphyllin VI induces caspase-1-mediated pyroptosis via the induction of ROS/ NF- $\kappa$ B/NLRP3/GSDMD signal axis in non-small cell lung cancer. Cancers (Basel) 2020;12:193.

26. Kim JY, Yu SJ, Oh HJ, et al. Panaxydol induces apoptosis through an increased intracellular calcium level, activation of JNK and p38 MAPK and NADPH oxidase-dependent generation of reactive oxygen species. Apoptosis 2011;16:347-58.

27. Hsieh CJ, Kuo PL, Hsu YC, et al. Arctigenin, a dietary phytoestrogen, induces apoptosis of estrogen receptornegative breast cancer cells through the ROS/p38 MAPK pathway and epigenetic regulation. Free Radic Biol Med 2014;67:159-70.

28. Kuroda K, Azuma K, Mori T, et al. The safety and antitumor effects of ozonated water in vivo. Int $\mathrm{J}$ Mol Sci 2015;16:25108-20.

29. Sharma P, Kumar S. Metformin inhibits human breast cancer cell growth by promoting apoptosis via a ROSindependent pathway involving mitochondrial dysfunction: pivotal role of superoxide dismutase (SOD). Cell Oncol (Dordr) 2018;41:637-50.

30. Mondal A, Bennett LL. Resveratrol enhances the efficacy of sorafenib mediated apoptosis in human breast cancer MCF7 cells through ROS, cell cycle inhibition, caspase 3 and PARP cleavage. Biomed Pharmacother 2016;84:1906-14.

31. Gorrini C, Harris IS, Mak TW. Modulation of oxidative stress as an anticancer strategy. Nat Rev Drug Discov 2013;12:931-47.

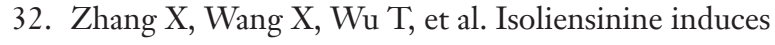
apoptosis in triple-negative human breast cancer cells through ROS generation and p38 MAPK/JNK activation. Sci Rep 2015;5:12579.

33. Hwang JT, Kwak DW, Lin SK, et al. Resveratrol induces apoptosis in chemoresistant cancer cells via modulation of AMPK signaling pathway. Ann N Y Acad Sci 2007;1095:441-8.

34. Nie P, Hu W, Zhang T, et al. Synergistic induction of erlotinib-mediated apoptosis by resveratrol in human non-small-cell lung cancer cells by down-regulating survivin and up-regulating PUMA. Cell Physiol Biochem 
2015;35:2255-71.

35. Huang YF, Zhu DJ, Chen XW, et al. Curcumin enhances the effects of irinotecan on colorectal cancer cells through the generation of reactive oxygen species and activation of the endoplasmic reticulum stress pathway. Oncotarget 2017;8:40264-75.

36. Angwa LM, Jiang Y, Pei J, et al. Antioxidant

Cite this article as: Tang S, Xu B, Li J, Zhong M, Hong Z, Zhao W, Zeng T, He X. Ozone induces BEL7402 cell apoptosis by increasing reactive oxygen species production and activating JNK. Ann Transl Med 2021;9(15):1257. doi: 10.21037/atm-213233 phytochemicals for the prevention of fluoride-induced oxidative stress and apoptosis: a review. Biol Trace Elem Res 2021. [Epub ahead of print]. doi: 10.1007/s12011-02102729-8.

(English Language Editor: J. Jones) 